\author{
Ana-Teodora Kurkina \\ Leibniz Institute for East and Southeast European Studies \\ University of Regensburg \\ Regensburg \\ ana-teodora.kurkina@extern.uni-regensburg.de
}

\title{
State Boundaries in the Minds of Men: Bulgarian Intellectuals Dividing the Balkans in the Mid-19th Century
}

\begin{abstract}
The correlation between the political imagination of intellectuals and their social ties is rarely linked to the state-building projects they produce. In most cases, political and social realities in regions do not coincide with the state boundaries sketched by intellectuals. Nevertheless, they do reflect the ideas of a narrow stratum of interconnected individuals that are easy to target and follow.

The current text introduces and analyses the individual ties that laid the foundation for state-building creativity in the context of the mid-19th century empires. It suggests that elites occupy a different place in the social hierarchy of the forming nations, creating their preliminary state boundaries mostly based on their own interconnections and personal considerations. While their plans do not necessarily succeed, they usually reflect the nature of the debates and concerns of a relatively small group that conceives them.

The case of the Bulgarian public actors in the mid-19th century offers a concentrated picture of a predominantly mobile intellectual elite engaged in the division of the Balkans. That elite included not only revolutionary thinkers like Georgi

This is an Open Access article distributed under the terms of the Creative Commons Attribution 3.0 PL License (creativecommons.org/licenses/by/3.0/pl/), which permits redistribution, commercial and non-commercial, provided that the article is properly cited. (c) The Author(s), 2019.

Publisher: Institute of Slavic Studies, Polish Academy of Sciences

Editor-in-chief: Jolanta Sujecka

Conception and academic editing of this issue: Katarzyna Roman-Rawska, Tomasz Rawski
\end{abstract}


Rakovski, but also poets and journalists like his younger contemporaries Hristo Botev and Lyuben Karavelov. Following their writings, one can produce a picture illustrating the correlation between state boundary-making and the imagi-nation of intellectuals. While the Bulgarian example is easy to follow, it is not unique. The hypothesis can be transferred to other cases and other elites engaged in statebuilding debates, especially those isolated from the reality of their target group due to their position in the social hierarchy, emigrant status or conflicting affiliations.

Keywords: state-building, elite theory, Balkan nationalism, Bulgarian nationbuilding, national indifference.

\section{Introduction}

tate-building projects reflect the realities perceived by the intellectuals

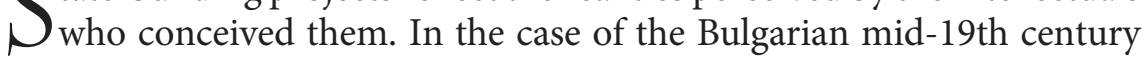
ideologists, the connection between their grand-scale political plans and their status of nationalist elites gains less attention than the separate analysis of their various projects. The article, thus, suggests that elites occupy a leading place in the social hierarchy of the forming nations, creating their preliminary state boundaries based on their social connections and seeking approval from their local and foreign peers. The paper claims that it was exclusively the 'devotion' of the masses to the national group that these elites required, not their involvement in state-building creativity. Investigating the documents produced by the public actors, the paper deals with their accounts of the 'national awakening', the ideal of what Bernhard Giesen calls 'the cultural project for modernity' (Giesen, 2009, pp. 239-241) and the realities of the post-Rum-Millet society in the Ottoman Empire with its mobility of intellectuals (Detrez, 2010, pp. 21-70).

Investigating the Bulgarian intellectuals as typical representatives of a narrow stratum of prominent agents attempting to appeal to a largely uninterested population, the paper suggests that their state-building creativity was a debate between the public actors themselves, their foreign peers and the Great Powers, and had little to do with the interests of their compatriots. The gradually growing popular involvement in the national cause demonstrates how mobile ideologists contributed to the creation of a seemingly unified and self-aware community, but continued to remain an elite, separated from the majority. Elites, therefore, can successfully manipulate the identities of their peers, influencing public opinion and affecting the position of their national group as a whole in the purview of elite theory (Domhoff, 2012, p. 24). 


\section{Who are the Elites?}

The status of a public actor partially determines the impact of his political claim and the extent of his influence (Lin, 2001, p. 3). That aspect may not be a discovery, but it brings out the vagueness of the term 'elites'. In the case of the nationalist state-builders in the mid-19th century Balkans, one faces an interesting dilemma. Before the Russian-Turkish War of 1877-1878, the signing of the Treaty of San Stefano and, subsequently, the Treaty of Berlin, most of the Bulgarian intelligentsia lived outside Bulgaria. In addition, most Bulgarian public actors were emigrants of peasant, merchant or low-middle class backgrounds, all born in the Ottoman Empire. They also fostered a pattern of thinking in which the Empire itself represented a focus point. This particularity assured their subsequent mobility and careers (Aust \& Schenk, 2015, p. 14).

These people lived in their own realities and one cannot view them separately from their environments. While researchers debate about the Bulgarian National Revival (Vezenkov, 2006, pp. 82-128) or attempt to comprehend the stages of nation-building in the Balkan cases (Hroch, 2015, p. 18), there is one issue that remains mostly omitted or taken for granted. While analysing grand-scale state-building creativity and the creation of political boundaries, one finds it difficult to define the position of the ideologists in the hierarchy of their host states or their national groups: were they indeed 'elites' and were they numerous and influential? The Bulgarian 19th-century nationand state-building debates are viewed as grandiose disputes that influenced everyone in the Balkans and beyond. But this may be questioned.

Inclusivity, in the case of nation-building, is more often a goal than a reality, and the existence of nationalist intellectuals only proves their role of transmitters and creators of ideas. After all, "written and printed communication is a powerful medium for the broadcast of ideas beyond their place and moment of origin" (Leerssen, 2011, p. 258). And, in the Bulgarian case, one would inevitably identify mobile agents as those who had received a better education than an average representative of their group (literate and ambitious individuals) and wished to upgrade their status through national emancipation. Thus, these public actors fit the description of all other European nationalist elites of the time: they were mobile, educated and politically active, leaving behind an impressive written legacy (Parusheva, 2011, pp. 141-176). Partially, it was due to this written legacy that writers, poets and journalists acquired the role of nationalist icons in the mid-19th century (Rigney \& Leerssen, 2014, p. 4). Shared cultural and political efforts brought them together, thus the Bulgarian intellectuals were neither unique nor isolated from an international context. But, on the other 
hand, they were isolated from the average Balkan Slavic-speaker, who did not actively participate in the nationalist 'Revivals'.

Following this idea of 'exceptionality', a contradiction appears. If, according to elite theory, "all political and other institutions of society are dominated by small groups of skilful individuals who know how to manipulate the instruments of power for their own purposes" (Woll, 1982, p. 46), then nationalist intellectuals could not be numerous, but had to dominate political institutions in their respective Empires. That, however, was rarely the case. They were often 'outcasts', problematic for their Empires, representatives of minorities with extraordinary ambitions and provocative state-building ideas (Mylonas, 2019, p. 8). Thus, one can retrospectively consider a charismatic revolutionary leader like Vasil Levski as a part of a forming nationalist elite, while bearing in mind that for the Ottoman authorities he qualified as a dangerous troublemaker with a status nowhere close to the high-ranking political elites of the state. The 'elite' status of such individuals, however, can be supported by three arguments: the Bulgarian elites all shared their educational backgrounds, they consisted of a limited number of people, and they engaged in their political debates mainly among themselves.

First, educational institutions in the Tanzimat Ottoman Empire and the Balkans contributed to the formation of ties between individuals. These were often the places where young Bulgarian revolutionaries met. The first Bulgarian intellectuals in the beginning of the 19th century mainly came from Greek circles (partially due to their Rum-Millet background and their affiliations with the Patriarchy in Constantinople). ${ }^{1}$ This tendency continued well into the mid-19th century, shifting slightly from the Greek-dominated imperial centres to places like Odessa, Moscow or new educational institutions in the Ottoman and even Habsburg Empires.

There were several education centres where most prominent Bulgarian public actors studied in the mid-19th century. In the 1840s and 1850s most of these individuals came from the Great School of the Nation in Constantinople (where they came from Greek schools in Bulgaria and Odessa). The revolutionary network itself started with these educated individuals. (Ivan Kishelski and Seliminski would be two of the numerous examples of the graduates of the Great School of the Nation) (Radev, 2007, p. 208). It was a combination of education and Bulgarian self-identification that made a person part of the nationalist 'elite' and elevated them in the hierarchy of the prospective state.

\footnotetext{
Neofit Bozveli can be regarded as one such individual; he became part of the Balkan intellectual circle mostly due to his religious affiliations (he became a monk around 1810) and his Greek education (Radev, 2007, pp. 133-134).
} 
Shared education contributed to the creation of elites, but it was also their small number that mattered. The Slavic population of the Balkans could respond to nation-building creativity, but those with an active political stance and possibilities to spread it remained a minority nonetheless. Genchev, for example, provides the following data regarding the pre-1878 number of Bulgarian students abroad (apparently those who were categorized by the respective governments as 'Bulgarian'): around 220 young Bulgarians studied at Russian universities (mainly in Kiev, Moscow and Odessa), 149 acquired an education in Constantinople (they mostly chose medical professions due to the newly opened institutions in the Empire), 156 studied in the Habsburg Empire, 71 chose Romanian lands, and Germany and France had even fewer Bulgarian students (Genchev, 2002, pp. 113-202). Thus, it is not difficult to deduce that not every single student was politically active. Furthermore, even among individuals involved in nationalist propaganda and state-building creativity like Karavelov and Botev, few had an inclination for a revolutionary career. Thus, in the end one comes across a narrow circle of friends brought together by educational opportunities.

Finally, besides the limited numbers of these elites, it was their limited audience that mattered. For example, even in the case of Georgi Rakovski, arguably the most influential Bulgarian ideologist in the mid-19th century, his readers and friends were few. Rakovski's Danubian Swan published in Belgrade was a 'popular' newspaper with 700 subscribers (Borshukov, 1957, p. 209). Considering the radical stance of the journal, 700 people does not seem a small number, compared to moderate and long-running journals like the Advisor or Macedonia. For example, Macedonia, the most widely read Bulgarian newspaper of the time, published by Petko Slaveykov, had around 3,600 subscribers to support it (Dinekov, Tsaneva, \& Sarandev, 1977, p. 324). Compared to the large number of Slaveykov's compatriots, the number of those even interested in the issues of his newspaper remained rather modest. The rest of the Bulgarian publications appeared mostly abroad (including the many projects of Hristo Botev and Lyuben Karavelov) and had even fewer subscribers (Botev, 1940, p. 499). One may wonder if those subscribers were indeed interested in state-building creativity or manipulated by the elites, who created the borders of their prospective states in their minds and discussed them exclusively with their peers. This claim can be tested. 


\section{Uninterested Majorities and Involved Minorities}

The Bulgarian elites were not born as a politically sensitive minority. For example, a revolutionary outlaw, an emigrant and one of the leaders of the April uprising of 1876, Panayot Hitov described his compatriots in his memoirs as follows:

Let me be forgiven for my words, but in our Motherland only the hajduks (outlaws), the shepherds and the cattle herders are free people. They are, at least, for a time, not subjected to the Turkish yoke and the violence of the chorbadjis. Yet, the Bulgarians are all ready to give their whole lives for just one free and happy minute. (Hitov, 1940, p. 5)

Hitov was certainly attempting to make his explanations fit his own revolutionary agenda (Hitov, 1982, pp. 49-64) and saw his aim primarily in awakening those less fortunate and 'nationally insensitive.' He was a person who integrated his peers into the "nation" (Deutsch, 1972, pp. 26-32). It was his acquaintance with Georgi Rakovski that turned him into a Bulgarian nationalist with a revolutionary career and a member of the nationalist elite (Hitov, 1940, p. 6). But even Hitov noticed the discrepancies between the nation-building ideology of his peers and the indifference of those whom he considered co-nationals.

In a letter addressed to Hitov, sent to Belgrade from Braila in 1874, his comrade Peev described the elder generations of Bulgarian emigrants in the Romanian town as follows: "In Braila, as well as in other Romanian cities, Bulgarians are immersed in a death-like slumber, and there's little hope that they may awaken since they became involved with Romanians and Turks. Under their influence, they have lost every national sentiment. I was stricken by the insensitivity of the colonists, who are almost exclusively Bulgarian and should have preserved their specific national life" (BIA, F. 87, IIA 8592). Further on Peev added: "Braila is a hard thing, brother Panayot! That kind of national indifference, for a man who is intently watching his nation's destiny, is hard to bear. Yet, there is not much to do. We should search and work" (BIA, F. 87, IIA 8592).

The idea of 'liberating' their kin from Ottoman rule inspired numerous individuals previously indifferent to each other and to their common ethnolinguistic ties (Detrez \& Plas, 2005, pp. 11-25). In less than a decade the whole struggle for national emancipation was propelled exclusively by a small number of active revolutionaries, who started out as mobile imperial subjects (Schenk, 2012, pp. 49-64). Most of their compatriots only gradually fell under their spell. This rapidly forming 'nationalist elite' tried to create their 'majority', while still being aware that this 'majority' cared little for their 
projects. Their mobility only tightened their connections to one another and made their intellectual circle smaller, which resulted in continuous contacts among Bulgarian students abroad (Peykovska, 2010, pp. 141-167). But their less mobile co-nationals remained excluded.

The representatives of the Bulgarian intelligentsia active in the 1860s and 1870 s typically lived abroad, starting with studies or business endeavours. ${ }^{2}$ Receiving an education from institutions of the post-Tanzimat Ottoman Empire, the Danubian lands or in Russia, they quickly fell under the influence of the circles of their compatriots. In Odessa, as well as in Braila or Bucharest, the number of Bulgarians pursuing either a merchant career or a similar business, grew with each new arrival of the younger generations. In bigger cities those young students, entrepreneurs or even outlaws were exposed to the ideas circulating in the local public sphere. Many found themselves under the influence of the most recent Romanticist political trends and involved with local revolutionaries (Pogolubko, 1972, p. 113). If their political stance outweighed or complimented their economic considerations, they had all the chances to join the elites adapting to the realities of their host states.

A foreign environment often artificially narrowed the circle of emigrants: they were almost always inevitably exposed to their fellow Bulgarians first. Then came their foreign peers. And, in this aspect, the situation became quite paradoxical: the more educated the emigrants became, the more they departed from most of their rural compatriots in Bulgaria and the more they were prone to collaborating with their foreign peers. ${ }^{3}$ And collaboration meant political survival.

Since it was political ideology that united the aspiring intellectuals, it became an inseparable part of the national identity that they perpetuated (Malesevic, 2006, p. 18). Those were not only students who ended up in each other's company, but also a group of people who could not escape exchanging ideas due to the similarity of the challenges they faced and the topics that they found interesting. In most cases, these groups eventually contributed to the creation of collective memory and nation-building ideals that inspired future generations (Rudometof, 2002, p. 7). But they also became the first elites who would eventually experience the divide between their ideals and social and political realities in their forming states, often turning into outcasts in the groups whose emancipation they had inspired (Perović, 2015).

\footnotetext{
2 Such were the cases of Hristo Botev, Lyuben Karavelov and many others. Karavelov even highlighted this aspect in his writings (Karavelov, 1862, pp. 15-16).

3 In one of his articles Miroslav Hroch raises the question of the discrepancies between the ideals of the Balkan students abroad and the realities of their homelands that struck a stark contrast between the Romanticist European trends and the working material (Hroch, 2015, p. 18).
} 


\section{Political Borders and Political Minds}

Reconciling political ambitions and Balkan realities, Georgi Rakovski even considered the possibility of merging Bulgarian with other South-Slavic languages to create a common tongue that could facilitate the union of the Balkan nations in 1857. Responding to a question from a journalist of a Serbian newspaper, Rakovski wrote: "We watch with great joy and happiness how our Slavic brothers consider us part of their group with their true brotherly sentiment and wish to contribute to our wellbeing more than anything else" (Rakovski, 1968, p. 349). Rakovski swayed between his ideas of the Bulgarian uniqueness and superiority and a dire need to cooperate with the other Balkan nations. After all, he was more alone than he would have admitted.

Rakovski became an exemplary Bulgarian nationalist but he remained an exceptional political ideologist even among his peers. A fellow emigrant and the leader of the Bulgarian Secret Central Committee, Ivan Kasabov, captured this particularity of his erstwhile political rival from the 1860s (Perry, 1993, p. 8). In his memoirs published in 1905, the story appeared with a tinge of fiction to it. He recollected his days in Ploiesti that were spent in the shadow of the Greek merchants and intellectuals running their businesses in the city (Kasabov, 1905/2009, pp. 46-47). Most of these individuals despised or ignored the local Bulgarian emigrants, seeing them as inferior and less educated, especially in the field of philology.

Rakovski, however, was a brilliantly schooled and multilingual person (he was also a rare guest of the café in Ploiesti, being equally well versed in modern and ancient Greek, Old Church Slavonic, Bulgarian and Romanian) (Adzhenov, 1896, p. 19). His knowledge, however, was overshadowed by his charisma. Kasabov wrote: "Besides that, he possessed a gift of clear and convincing speech" (Kasabov, 1905/2009, p. 46). Rakovski's research methods were questionable at best, but Kasabov described the result in the following passages:

Rakovski found a piece of chalk and wrote a decent number of Ancient Greek words with all the accents and diacritics on the table. He then explained what each of those accents meant and which letters had disappeared with time. The Greek scholar nodded in approval. Then Rakovski wrote entire words including the vanished letters and received purely Bulgarian terms as a result, claiming that they had been borrowed from Bulgarian and that the Bulgarian language had existed before Greek and that the latter had been modelled on the basis of Bulgarian" (Kasabov, 1905/2009, p. 47).

As strange as it may seem to a philologist, Rakovski's linguistic escapades stirred the otherwise mundane social life in Ploiesti, attracting the attention 
of Romanian and Greek 'experts', each claiming their right. Considering the general indifference of most of their compatriots and the paradoxical familiarity of these individuals with one another pointed out by Kasabov, one can come to an interesting conclusion. Despite all the linguistic banter and nationalist disputes, the local elites inevitably ended up in one another's company. Most of them knew the others. Newcomers usually became witnesses to such performances as the one delivered by Rakovski (if one can trust the veracity of Kasabov's memoirs at least partially), and suddenly became proud of their Bulgarian ancestry. Here, Kasabov's conclusion underlines this point: "Afterwards Romanians kept teasing the Greeks because of that accident and the local Bulgarians became so inspired that they switched places with the Greeks and started ignoring and despising them" (Kasabov, 1905/2009, p. 47). This outcome, thus, was only an example of the influence a well-educated member of the nationalist elites could exercise. But when it came to sketching borders and dividing the Balkans, only the elites took part in the enterprise.

Most state-building projects were produced as compromises by the elites trying to negotiate the borders of their prospective state and nation with their neighbours and the Great Powers. Aware of their limited resources, many Bulgarian intellectuals opted for grand-scale projects (Lalkov, 1994), often demonstrating optimistic expectations of unity and mutual understanding (Todorov, 2002). The Great Powers, on the other hand, were perceived by the emigrants as indecisive swaying parties whose approval or disapproval could threaten or support the Bulgarian state (Seliminski 1979, p. 160). The elites concentrated on convincing their countrymen to rebel, following the Greek and Serbian examples (Stavrianos, 1958, pp. 230-300). But it was only the general support of the masses that interested them. The essence of their projects was aimed at their fellow intellectuals - both foreign and Bulgarian.

The transitional period of 1860s-1870s includes various examples of attempted cooperation with regional and foreign intellectuals and continuous attempts to bring more Bulgarians into the national club as supporters. Partially ignited by Rakovski's examples, a political project saw light in the early 1860s. A lawyer, a revolutionary and one of the organizers of the first Bulgarian legion in Serbia in 1862 (Traikov, 1973, pp. 245-255), Ivan Kasabov became a prominent propagator of the Bulgarian national movement and the driving force behind the new plan. He, very much like Rakovski, attempted to bring foreign cooperation into his nationalist discourse through the Bulgarian Secret Central Committee.

This organization emerged in 1866 (when Rakovski's attempts to build a united Balkan military force failed) (Crampton, 1997, p. 137) as one 
of the important branches of Bulgarian revolutionary organizations in Serbia, Bulgaria and Russia. It was greatly inspired by the liberal Romanian intellectuals who later forced Alexandru Ioan Cuza, the exiled prince of the United Principalities, rapidly escalating Romanian-Ottoman relations (Burmov, 1974, pp. 58-81). Finding themselves in a difficult situation, the Romanian liberals turned to the Bulgarian emigrants to assure themselves the potential support of a minority within the borders of the Ottoman Empire. The Bulgarian elites could provide their Romanian peers with help to face a common threat. While Rakovski was less prone to ally himself with the ideologists who had overthrown Cuza, ${ }^{4}$ Ivan Kasabov viewed the tensions between newly emerged Romania and the Ottoman Empire as an opportunity to organize a Bulgarian uprising in the Ottoman lands (Kasabov, $1905 / 2009$, pp. 50-54).

Kasabov was arguably the mastermind behind the "Sacred Coalition between Romanians and Bulgarians", a document prepared by the Romanian side and the Bulgarian Secret Central Committee in Bucharest. It turned into a bond linking together the Bulgarian quest for national emancipation and the interests of the Romanian state. In his memoirs, revolutionary Hristo Makedonski would write that the aim of the enterprise was to forge an understanding between the Romanian and Bulgarian state-builders (Makedonski, 1973, pp. 25-32). Subsequently, the creation of a Bulgarian state either as a part of a Balkan confederation or as a part of the Ottoman Empire was expected. The project itself was rather vague, with no definite rules of application or even any specific ruling system that was to govern the two nations. And it was Bulgarian emancipation that remained the focus of the 'Sacred Coalition'. Kasabov wrote that both an "autonomous Bulgarian principality", a "vassal state" under the Sultan or a federative union with other non-core groups could become an acceptable option for the Bulgarian nation. A grand-scale project allowed one to negotiate the borders of the state and to engage influential foreign supporters.

\section{Representatives of the National Group}

Bulgarian emigrants in the 1870s could not join other groups on an equal footing (mostly their desire not to be assimilated came from their ambition, although they could opt for a career in the Empire). Thus, they created their own groups and societies, often evading authorities. Certainly,

\footnotetext{
According to Panayot Hitov, Cuza took a liking to Rakovski and supported his activities, while Cuzàs opponents, including the Brătianu brothers, regarded him and his ideas as a threat to Romanian external politics (Hitov, 1982, p. 196). It was possibly due to Rakovski's friendly relations with Cuza that he was unwilling to forge an alliance with the Romanian liberals afterwards.
} 
Bulgarian revolutionary organizations and their activities came under police scrutiny in the Romanian lands, the Ottoman Empire, Serbia and Russia. But their attitudes were predictably different. If the Ottoman authorities mostly persecuted these organizations, the Russian Empire, while intolerant to socialist, anarchist and overall revolutionary ideas, seemed to turn a blind eye to the literary societies whose nationalism was dressed as an attempt to forge Slavic bonds between brotherly nations. It could even facilitate the recruitment processes of these organizations.

The Empires often contributed to the emergence of these tightly connected cells of Bulgarian public actors. Among those individuals, one can loosely discern two types: moderate and those who found company among Russian socialists and revolutionaries (Constantinescu-Iași, 1950, pp. 14-16). Karavelov and Botev, for example, both sought allies among those who were considered unacceptable by the Empires. In Karavelov's case, these connections resulted in his arrest by the Austro-Hungarian authorities due to his connections with Serbian federalists Vladimir Jovanović and Svetozar Miletić (Armour, 2014, pp. 92-93). Furthermore, most of the emigrant elites pursued the course of national emancipation and attracted allies, but some preferred less perilous ways of achieving their goals.

The 'moderate' public actors tended to seek official cooperation. In Russia, due to the Russian Slavophiles and their circles, the public actors could find numerous opportunities to build a career and promote their cause. Many of them would later return from Russia bitterly disappointed with the Tsarist autocracy (Botev can be considered just one such example), but some would attempt to create a link between their interests and those of the Empire. Ivanov, the head of the 'Bulgarian society for the spread of education among the Bulgarians', wrote to a prominent Russian Slavophile, Ivan Aksakov, on 22 December 1876 that "the ladies' department of the Slavic committee wanted to educate 50 future teachers for Bulgaria" and offered a girl named Roza Zhivkova, whose mother had no money and whose father was dead, as a candidate (GARF, Fond 1750, op. 2, ed. hr. 36). In another letter to Aksakov (dated 28 January 1877), Ivanov would recommend another Bulgarian young lady, Anastasia Obretenova from Ruschuk, as a potential teacher. Obretenova's family was deeply involved in the Bulgarian national cause, which resulted in the death of two of her brothers, the imprisonment of a third brother and the emigration of a fourth (GARF, Fond 1750, op. 2, ed. hr. 36, p. 32). The life story of this Bulgarian girl may not be exceptional (although it became quite interesting following 1878, when she married writer and journalist Zahari Stoyanov), but it sheds light on the ways the elites reproduced, recruiting new members from among their own relatives and acquaintances. 
In many cases those newly educated friends and relatives engaged in state-building creativity under the ruse of literary circles and educational societies. Odessa, for example, harboured both male and female public actors and poets, many of whom would eventually use the connections and publishing opportunities those literary circles offered for their political purposes. Nayden Gerov, one of the first Bulgarian public actors to settle in Odessa, was a link connecting politically involved elites, enabling their communication and bringing younger contemporaries to the city (Radev, 2007, p. 208).

The individuals supported by Gerov included both Lyuben Karavelov and Hristo Botev, whose political plans stirred great controversies among their peers. Karavelov, a Balkan federalist, idealistically envisioned the Balkan nations as united against the ever-present Ottoman threat (Nikolov, 1996, pp. 36-41). As an emigrant living in Russia, Karavelov was not enthusiastic about following the Russian lead on the matter of state-building (Nikolov, 1996, pp. 17-24), turning to the examples of Switzerland and the United States. Yet he desperately needed to offer a compromise to the Great Powers.

The Great Powers rarely favoured Balkan federative plans. Local elites saw them as idealistic, while new nation-states could threaten their regional supremacy and the balance of power. The Bulgarian intellectuals were careful, thus most of their projects became vague: the borders of the envisioned nation-state existed exclusively in the minds of their creators and were criticized, praised and scrutinized exclusively by their peers. They did not necessarily need to be Bulgarian. They only needed to belong to the narrow circle of European Romanticist intellectuals. For example, Karavelov was greatly inspired by the revolution of 1848 and its state-building ideas, becoming a federalist (Dragova, 1992, p. 105). Alexandru Ioan Cuza, the Prince of the Danubian Principalities, similarly showed interest in the federative projects of the post-1849 Hungarian emigrants and Rakovski's ideas about unifying the Balkans (since he saw the Ottoman Empire as a great threat to Romanian statehood). Bakunin, a Russian revolutionary, openly praised Lajos Kossuth's post-1849 confederative efforts (Billington, 1999, pp. 329-330). Those were all intellectual elites discussing their political projects and arguing about borders and states among themselves. One rarely finds meaningful responses from outsiders.

The quest for national emancipation turned into a national competition between those who saw themselves as representatives of their nations, often lamenting about the lack of understanding from their foreign peers. That disappointment was expressed by Petko Slaveykov in his article "Serbia and the Bulgarians", in which he remarked that "wrong interpretations" and "mutual distrust" made the two neighbouring, closely related nations 
succumb to mutually unbeneficial policies (Danova, 1996, p. 92). But those were squabbles between Serbian and Bulgarian intellectuals assuming the roles of Balkan elites. Most of the population cared little about these issues, unless their nationalist elites elaborated on the topic.

In 1886 one can come across an account in which a mobile public actor remembered his successful experiences, now publishing them as textbook materials for his peers. Iliya Blaskov, an established Bulgarian writer, an emigrant and a revolutionary, left a curious statement regarding the 'awakening' of the peasant masses in his story "Uncle Dobri" which takes place before the formation of the Principality. In this story, a Bulgarian priest, a mobile intellectual, allegedly driven away from his previous locations by Greeks, came to a predominantly Turkish-speaking village with a mixed Christian and Muslim population, where he started preaching. Through the priest named Ivan, a local elderly man called Dobri learned about the Bulgarian Empire, the Ottoman conquest, the nation and, inevitably, the 'treachery of the Greeks', becoming a nationally sensitive Bulgarian (Blŭskov, 1940, pp. 175-176). The previous cohabitation crumbled to pieces with the help of the mobile preacher, inspired by Rakovski's ideas. As a result, the previously indifferent Dobri "would go out, meet a Turk and regard him as a fly: he could have squeezed his throat with two fingers and choked the soul from him" (Blŭskov, 1940, p. 177). Such attitudes persisted well into the 1880s, successfully recruiting enough nationally sensitive Bulgarians for the now political elites to continue their project. But Dobri did not become a member of the elite. He was still only vaguely aware of what the Bulgarian state with its borders was or could be.

The group of mobile ideologists did not grow following the RussianTurkish War of 1877-1878. It remained the same cluster of nationally sensitive ideologists that catered to the predominantly indifferent majority through their teaching practices, publications and access to public resources. The initial mobility of these agents and their ties formed during the years of exile transformed into political connections (Parusheva, 2011, pp. 141-176). The Tarnovo constitution of 1879 guaranteed freedom of the press, securing the right to expression that remained inaccessible to the cohorts of travelling emigrants (Borshukov \& Topencharov, 1962, p. 18). Sofia quickly became an intellectual centre where most of the books, newspapers and pamphlets were published. Simultaneously, censorship that had previously been managed by the Ottoman authorities (or the Russian or Romanian host states) became the responsibility of the politicians of the Bulgarian principality.

Beginning from 1883 and continuing after Bulgaria's unification with Eastern Rumelia, various restrictions were imposed by the government (Tankova, 2004, p. 151). Anti-government stances now posed a threat 
to the Bulgarian state. With the growing number of publications in Bulgarian (compared to 3,000-4,000 subscriptions of the most popular pre-1878 newspaper Macedonia and various publications scattered across Europe), the circle of information extended. Subsequently, revolutionaries turned into politicians. From a pursued outlaw, Stefan Stambolov turned into a pursuer, enforcing the laws of the Bulgarian state. From an elite dividing the Balkans in their minds, the intellectuals gradually became the leaders of a national group.

\section{Conclusions}

The paper offered a brief analysis of the mechanisms the educated mobile elites used to influence their compatriots, relying on their ties with one another and their active practices of publishing, teaching and recruiting the uninvolved. It suggested that the elites occupy a strategically important place in the social hierarchy of the forming nations, imagining their preliminary state boundaries mostly based on their own political inspirations and personal connections. In many cases, it is that exclusive position of the elites that isolates them from the less-involved majorities and strengthens their connections with each other. In the end, intellectual elites often become reflections of social and political change (Stojanović, 2013). And, while they remain instrumental for the creation and perpetuation of national ideologies, intellectual elites' place in the social hierarchy is often that of an outsider.

Intellectuals shaped the perceptions of the uninvolved, who only partially mattered to their cause. One may also view migration as an effective method of isolating a national group and allowing it to target susceptible newcomers, practicing nation- and state-building doctrines on a smaller number of individuals. Most of the Bulgarian state-builders (especially when it came to professional writers, historians, etc.) in the mid-19th century were, at some point in their lives, emigrants or travelling agents living within Empires and constantly negotiating their positions with the local authorities. They were often culturally isolated from their compatriots, but never isolated from their fellow intellectuals (Leerssen, 2011, p. 266). Often, international connections and an interest in the European idea distinguished these intellectuals and highlighted the particularity of their position.

The most educated or ideologically driven adopted the roles of elites, making their compatriots nationally sensitive. These elites continued to exist following 1878, often including individuals related to the previous cohorts of ardent nationalists. Lyuben Karavelov's brother Petko became a politician whose whole family was involved in both the cultural and the political life of the principality; former emigrant Ivan Vazov became 
a celebrated writer of international bestsellers (Eser, 2015, p. 211). Other professionals returned to the Principality only to continue their political creativity once launched abroad.

In the decades following 1878, one witnesses the rise of the Bulgarian state, following the successes and disappointments of the intellectuals that helped shape its ideological framework. Eventually, these intellectual elites acquired possibilities of applying their political templates in the new conditions. While they claimed to represent most of their compatriots, they never truly did. Many of them became symbolic figures and reference points for their society, reaching the ranks of national heroes and prominent ideologists like Rakovski, Levski or both Karavelov brothers. They became spokesmen for the majority that remained mostly indifferent to their efforts, rarely involving themselves in their debates. Intellectuals continued to cling to their circles, where they kept debating, adhering to the rules of their smaller community that remained isolated from the general public (Collins, 2014, pp. 190-196). And those were, most likely, the specific interests and ambitions that assured them a special place in the societies of their forming nation-states.

\section{Archive Materials}

Bŭlgarski istoricheski arkhiv [BIA] F. 87, IIA 8592.

Gosudarstvennyı̆ Arkhiv Rossiǔskoı̆ Federatsii [GARF] Fond 1750, op. 2, ed. hr. 36.

\section{References}

Adzhenov, I. (1896). Svedeniia i zapiski za zhivota na Georgi Sava Stoikov Rakovski: Pocherpnŭti iz ustmennite negovi raskazi, sŭshto i iz mnogobroinite mu sŭchineniia, koito prigotvikha pochvata za politicheskoto osvobozhdenie na Bŭlgariia: Naredil i izdava Ivan P. Adzhenov. Ruse: Tipo-Hromo Litografiia na Drobniak i Krŭstev.

Armour, I. (2014). Apple of discord: The "Hungarian factor" in Austro-Serbian relations, 1867-1881. Purdue: Purdue University Press.

Aust, M., \& Schenk, F. B. (2015). Einleitung: Autobiographische Praxis und Imperienforschung. In M. Aust \& F. B. Schenk (Eds.), Imperial subjects: Autobiographische Praxis in den Vielvölkerreichen der Romanovs, Habsburger und Osmanen im 19. und frühen 20. Jahrhundert (Vol. 1, pp. 11-39). Köln: Bohlau. https://doi.org/10.7788/9783412502539-001

Billington, J. (1999). Fire in the minds of men: Origins of the revolutionary faith. London: Transaction Publishers.

Blŭskov, I. (1940). Diado Dobri: Edin od starite nashi istinski narodni muzhe. In I. Bogdanov, Izbrani proizvedeniia: Vol. 1. Uvod i belezhki. Sofiia: Hemus. 
Borshukov, G. (1957). Istoriia na bŭlgarskata zhurnalistika ot zarazhdaneto na bŭlgarskiia pechat do osvobozhdenieto prez 1878 g.: Lektsii. Sofiia: Nauka i izkustvo.

Borshukov, G., \& Topencharov, V. (1962). Zarazhdane i razvoi na bŭlgarskiia periodichen pechat. In D. Ivanchev (Ed.), Bŭlgarski periodichen pechat 1844 1944: Anotiran bibliografski ukazatel (Vol. 1, pp. 1-20). Sofiia: Nauka i izkustvo.

Botev, H. (1940). Pŭlno sŭbranie na sŭchineniiata: Vol. 3. Statii po politicheski i obshtestveni vŭprosi (M. Dimitrov, Ed.). Sofiia: Knizharnitsa Nov svet.

Burmov, A. (1974). Taen tsentralen bŭlgarski komitet (Obrazuvane i pŭrvi period na razvitiieto $\mathrm{mu}$ ). In A. Burmov, Izbrani proizvedeniia v tri toma (Vol. 2). Sofiia: Istoricheski pregled.

Collins, R. (2014). Interaction ritual chains. Princeton, NJ: Princeton University Press.

Constantinescu-Iaşi, P. (1950). Din activitatea lui Hristo Botev şi a altor revoluţionari bulgari din Bucureşti: comunicare. Bucureşti: Editura de stat.

Crampton, R. J. (1997). A concise history of Bulgaria. Cambridge: Cambridge University Press.

Danova, N. (1996). Obrazŭt na gŭrcite, sŭrbite, albancite i rumuncite v bŭlgarskata knizhina. In A. Zheliazkova (Ed.), Vrŭzki na sŭvmestimost $i$ nesŭvmestimost mezhdu khristiiani i miusiulmani v Bŭlgariia (pp. 57-135). Sofiia: Nauka i izkustvo.

Detrez, R. (2010). Understanding the pre-nationalist Balkans: The "Romaic" community. In P. Kitromilides \& A. Tabaki (Eds.), Greek-Bulgarian relations in the age of national identity formation (pp. 21-70). Athens: Institute for Neohellenic Research, National Hellenic Research Foundation.

Detrez, R., \& Plas, P. (2005). Convergence and divergence in the development of Balkan cultural identity. In R. Detrez \& P. Plas (Eds.), Developing cultural identity in the Balkans: Convergence vs divergence (pp. 11-25). Brussels: Peter Lang.

Deutsch, K. (1972). Nationenbildung, Nationalstaat, Integration. Düsseldorf: Bertelsmann Universitätsverlag.

Dinekov, P., Tsaneva, M., \& Sarandev, I. (1977). Rechnik na bŭlgarskata literatura (Vol. 2). Sofiia: Izdatelstvo BAN.

Domhoff, G. (2012). An invitation to a four-network theory of power: A new viewpoint compatible with elite theory. Historical Social Research / Historische Sozialforschung, 37(1), 23-37.

Dragova, N. (1992). Svetozar Markovic, Liuben Karavelov i balkanskata kulturna tradiciia pred noviia universalizam na 19 vek. In N. Tasić, M. Maticki, \& M. Stojanović (Eds.), Svetozar Marković and Lyuben Karavelov in the context of Slavic literature (pp. 103-117). Beograd: Institut za književnost i umetnost, SANU.

Eser, U. (2015). A versatile text for the propaganda of nationalism: Under the Yoke by Ivan Vazov. In D. Stamatopoulos (Ed.), Balkan nationalisms and the Ottoman Empire: Vol. 1. National movements and representations (pp. 207-223). Istanbul: the ISIS Press.

Genchev, N. (2002). Bŭlgaro-ruski kulturni obshtuvaniia prez Vŭzrazhdaneto. Sofiia: Lik. 
Giesen, B. (2009). The three cultural projects of modernity. International Political Anthropology, 2(2), 239-241.

Hitov, P. (1940). Moeto pŭtuvane po Stara Planina (A. Burmov, Ed.). Sofiia: Hemus.

Hitov, P. (1982). Kak stanakh khaidutin. Sofiia: Izdatelstvo Otechestvo.

Hroch, M. (2015). Is there a southeast European type of nation-formation? In D. Stamatopoulos (Ed.), Balkan nationalism(s) and the Ottoman Empire (Vol. 3, pp. 13-29). Istanbul: The Isis Press.

Karavelov, L. (1862/1985). Sŭbrani sŭchineniia v dvanadeset toma (Vol. 6). Sofiia: Bŭlgarski pisatel.

Kasabov, I. (2009). Moite spomeni ot Vŭzrazhdaneto na Bŭlgariia s revoliutsioni idei. Sofiia: Izdatelska kŭshta Sineva. (1st ed. 1905).

Lalkov, M. (1994). Ot nadezhda kŭm razocharovaniie: Ideiata za federatsiia $v$ balkanskiia iugoiztok. Sofiia: Vek 22.

Leerssen, J. (2011). Viral nationalism: romantic intellectuals on the move in nineteenth-century Europe. Nations and Nationalism, 17(2), 257-271. https://doi. org/10.1111/j.1469-8129.2010.00478.x

Lin, N. (2001). Social capital: A theory of social structure and action. Cambridge: Cambridge University Press. https://doi.org/10.1017/CBO9780511815447

Makedonski, K. (1973). Zapiski na Khristo Makedonski 1852-1877. Sofiia: Otechestven Front.

Malesevic, S. (2006). Identity as ideology: Understanding ethnicity and nationalism. London: Palgrave Macmillan. https://doi.org/10.1057/9780230625648

Mylonas, H. (2019). Nation-building policies in the Balkans: An Ottoman or a manufactured legacy? Nations and Nationalism, 25(3). https://doi.org/10.1111/ nana.12499

Nikolov, I. (1996). Bŭlgarite i sŭsednite narodi v publitsistikata na Rakovski, Karavelov, Botev, Iavorov. Sofiia: Makedoniia Press.

Parusheva, D. (2011). The web of power and power of the webs: Political elites in Romania and Bulgaria in the late nineteenth century and their networks. In N. Clayer \& T. Anastassiadis (Eds.), Society and politics in South-Eastern Europe during the nineteenth century (pp. 141-176). Athens: Alpha Bank Historical Archives.

Perović, L. (2015). Dominantna i neželjena elita: Beleške o intelektualnoj i političkoj eliti u Srbiji (XX-XXI vek). Beograd: Dan Graf.

Perry, D. (1993). Stefan Stambolov and the emergence of modern Bulgaria, 1870-1895. Durham: Duke University Press.

Peykovska, P. (2010). Bŭlgari-studenti v ungarski universiteti i visshi uchebni zavedeniia prez vtorata polovina na XIX v. i pŭrvata polovina na XX v. In P. Peykovska \& G. Demeter (Eds.), Auxiliary historical disciplines: Vol. 6. Political, social, economic and cultural elites in the Central- and East-European states in modernity and post-modernity (pp. 141-167). Sofia.

Pogolubko, K. (1972). Ocherki istorii bolgarsko-russkikh revoliutsionnykh sviazeŭ (60-70 gody XIX veka). Chisinau: Stiinta. 
Radev, I. (2007). Istoriia na bŭlgarskata literatura prez Vŭzrazhdane. Veliko Tŭrnovo: Abagar.

Rakovski, G. (1968). Vŭzgledi, deĭnost i zhivot: Materialni dokumenti (Vol. 2). Sofiia: BAN.

Rigney, A., \& Leerssen, J. (2014). Fanning out from Shakespeare. In J. Leerssen \& A. Rigney (Eds.), Commemorating writers in nineteenth-century Europe: Nation-building and centenary fever (pp. 1-24). London: Palgrave Macmillan. https://doi.org/10.1057/9781137412140_1

Rudometof, V. (2002). Collective memory, national identity, and ethnic conflict: Greece, Bulgaria, and the Macedonian question. Westport, CT: Praeger.

Schenk, F. B. (2012). "Ich bin des Daseins eines Zugvogels müde”: Imperialer Raum und imperial Herrschaft in der Autobiographie einer russischen Adeligen. L'Homme, 23(2), 49-64. https://doi.org/10.7767/lhomme.2012.23.2.49

Seliminski, I. (1979). Izbrani sŭchineniia (N. Kochev \& M. Bŭchvarov, Eds.). Sofiia: Nauka i izkustvo.

Stavrianos, L. (1958). The Balkans since 1453. New York, NY: Rinehart.

Stojanović, D. (2013). Iza zavese: Ogledi iz društvene istorije Srbije, 1890-1914. Beograd: Udruženje za društvenu istoriju.

Tankova, V. (2004). Bŭlgarskoto zakonodatelstvo po pechata 1879 - 1944. In T. Adamova et al., Mezhdu tri veka: Sŭdbi, iliuzii i svidetelstva za chudoto, narecheno zhurnalistika (pp. 150-162). Sofiia: Sŭiuz na bŭlgarskite zhurnalisti.

Todorov, V. (2002). Znam gi az tiakh! Sŭrbiia i sŭrbite v bŭlgarskata literatura. Varna: LiterNet. Retrieved from http://liternet.bg/publish4/vtodorov/znam/ upomenanie.htm

Tră̌kov, V. (1973). Georgi Stoǔkov Rakovski: Biografiia. Sofiia: Izdatelstvo na Bŭlgarskata akademiia na naukite.

Vezenkov, A. (2006). Ochevidno samo na prŭv pogled: Bŭlgarskoto vŭzrazhdane kato otdelna epokha. In D. Mishkova (Ed.), Balkanskiiat 19 vek: Drugi prochiti (pp. 82-128). Sofiia: Riva.

Woll, P. (1982). Public policy. New York, NY: University Press of America. 


\section{Государственные границы в сознании людей: деление Балканов болгарскими интеллектуалами в середине 19 века}

Корреляция между политическим воображением интеллектуалов и их социальными связями редко ассоциируется с проектами по конструированию государства, которые они создают. В большинстве случаев, политические и социальные реалии в различных регионах не совпадают с государственными границами, начертанными политическими активистами. Они отражают идеи узкой прослойки контактирующих индивидумов, чьи действия легко увидеть и проследить.

Данный текст рассматривает и анализирует личные связи политических активистов, которые заложили основы проектов по конструированию государства в контексте империй середины 19 века. Автор утверждает, что интеллектуальные элиты занимали особое место в социальной иерархии формирующихся наций, создавая предварительные государственные границы, базируя их на своих личных связях и идеях. Их планы не венчались успехом во всех случаях, однако, они отражали природу дебатов и интересов маленькой группы, которая их выражала, но никак не всего населения.

Случай болгарских политических активистов середины 19 века представляет собой пример преимущественно мобильной элиты, вовлеченной в раздел Балканского полуострова. Эта элита включала в себя не только революционных мыслителей как Георгий Раковский, но также поэтов и публицистов как его младшие современники Христо Ботев и Любен Каравелов. Анализируя оставленные ими письменные документы, можно воспроизвести модель, иллюстрирующую корреляцию между конструированием государственных границ и политическим воображением интеллектуалов. Болгарский пример предлагает достаточное количество материала для проведения исследования, однако, он далеко не уникален. Данная система может буть перенесена на другие случаи, в которых фигурируют элиты, причастные к конструированию государственных границ. Наиболее подробно данная модель иллюстрирует деятельность представителей элиты, которые находятся в изоляции от своей целевой группы изза своего положения в социальной иерархии, статуса эмигранта или противоречивых идентичностей.

Ключевые слова: государственное строительство, теория элит, балканский национализм, болгарское нациостроительство, национальная индифферентность. 


\section{Granice państwowe w umysłach ludzkich: dzielenie Bałkanów przez bułgarskich intelektualistów w połowie XIX wieku}

Korelacja między polityczną wyobraźnią intelektualistów a ich więziami społecznymi rzadko jest kojarzona $\mathrm{z}$ tworzonymi przez nich projektami budowy państwa. W większości przypadków regionalne realia polityczne nie pokrywają się z granicami państwowymi wyznaczonymi przez działaczy politycznych. Odzwierciedlają one idee wąskiej warstwy wzajemnie powiązanych jednostek, których działania można łatwo dostrzec i prześledzić.

Niniejszy tekst analizuje osobiste powiązania aktywistów politycznych, którzy stworzyli podstawy dla projektów budowy państw w epoce imperiów połowy XIX wieku. Autorka twierdzi, że elity intelektualne zajmowały szczególne miejsce w społecznej hierarchii formujących się narodów, tworząc wstępne granice państwowe w oparciu o osobiste więzi i idee. Ich plany nie we wszystkich przypadkach były zwieńczone sukcesem, lecz odzwierciedlały specyfikę debat i interesów małej grupy, która je wyrażała, a nie całej ludności.

Przypadek bułgarskich aktywistów politycznych połowy XIX wieku stanowi przykład mobilnej elity zaangażowanej w podział Półwyspu Bałkańskiego. W skład tej elity weszli nie tylko rewolucyjni myśliciele jak Georgi Rakovski, ale także poeci i publicyści jak Christo Botev i Luben Karavelov. Analizując pisane przez nich dokumenty, można odtworzyć model ilustrujący korelację pomiędzy konstruowaniem granic, a polityczną wyobraźnią intelektualistów. Bułgarski przykład oferuje wystarczającą ilość materiału do badania, lecz jest daleki od bycia wyjątkowym. Model ten może być przeniesiony do innych przypadków, w których biorą udział elity zaangażowane $\mathrm{w}$ konstruowanie granic państwowych, jednocześnie znakomicie ilustruje działalność przedstawicieli elit, którzy są odizolowani od grupy docelowej ze względu na sprzeczną z nią tożsamość, status emigranta lub pozycję w hierarchii społecznej.

Słowa kluczowe: budowanie państw, teoria elit, bałkański nacjonalizm, budowanie narodu bułgarskiego, indyferencja narodowa.

Przekład z języka rosyjskiego

Katarzyna Roman-Rawska

\section{Note}

Ana-Teodora Kurkina, Leibniz Institute for East and Southeast European Studies, University of Regensburg, Regensburg.

ana-teodora.kurkina@extern.uni-regensburg.de

The preparation of the article was self-funded by the author.

No competing interests have been declared. 